\title{
Effects of 3-Hydroxy Isoxazoles as Soil-Fungicides in Relation to Their Chemical Structures*
}

\author{
Yukiyoshi Takahi**, Toshiro Nakanishi**, \\ Kazuo Tomita** and Shoji Kamimura*** \\ 高日幸義・中西逸朗・富田和男・上村昭二：3-Hydroxy Isoxazole 誘導体の \\ 土靖殺菌剤としての効果一その化学構造と活性について
}

\begin{abstract}
Summary
Effects of a number of 3-hydroxyisoxazole derivatives substituted at 4 and/or 5 position of isoxazole ring on cucumber Fusarium wilt (Fusarium oxysporum f. cucumerinum) and cucumber seedling damping-off (Corticium rolfsii, Pythium aphanidermatum), and their antimicrobial activities on potato-sucrose-agar (PSA) medium and in soil were studied.

Greenhouse evaluation (in vivo)-Compounds substituted with alkyl groups or hydrogen atom at 5-position of isoxazole ring were generally more effective than the derivatives substituted with aryl groups under greenhouse conditions. The effectiveness decreased in the following order:

methyl $>$ ethyl $>$ propyl $>$ butyl $>$ hydrogen.

Replacement of hydrogen atom at 4-position of isoxazole ring by nitro or methyl group or by chlorine or bromine atom reduced effectiveness against Fusarium wilt or seedling damping-off.

Laboratory evaluation (in vitro)-Inhibitory effects of these derivatives on PSA medium against $R$. solani, $C$. rolfsii and $P$. debaryanum were generally strengthened in proportion to increase in the number of carbon atoms of alkyl groups at 5-position with the exception of activities against $F$. oxysporum. The growth inhibition of $C$. rolfsii by these derivatives in soil was not proportional to increase in the number of carbon atoms of alkyl groups at 5-position, and 3-hydroxy-5-methylisoxazole (hymexazol) showed the highest activity in soil. On the other hand, replacement of alkyl groups at 5-position by phenyl group enhanced inhibitory effect on PSA medium, but reduced it in soil. Effect of hymexazol thus selected as the most effective soil-fungicide in this series of compounds was studied extensively by large scale tests in a greenhouse. (Received November 28, 1973)
\end{abstract}

\section{Introduction}

Iwai and Nakamural) found that 3-hydroxyisoxazoles substituted in the 5-position were obtained from the reaction of acetylene carboxylic acid esters and hydroxylamine under a strong alkaline condition. Tomita $e t a l^{2}$. reported that 5-aryl- or alkyl- substituted 3-hydroxyisoxazole derivatives

* The summary of this study was presented at the Annual Meeting of the Phytopathological Society of Japan, Tokyo, April 6-7, 19703).

** Agricultural Chemicals Research Laboatories, Sankyo Co., Ltd., Shiga, Japan. 三共 (株) 農薬研究 所, 野洲

*** Fermentation Research Laboratories, Sankyo Co., Ltd., Tokyo, Japan 三共 (株) 醇酵研究所, 東京 
were synthesized from the corresponding $\alpha, \beta$-dihalogenopropionic acid esters and hydroxylamine in the presence of a large excess of alkali hydroxide.

On the other hand, authors have tried to find out the most effective chemical for control of Fusarial disease, which is one of the most troublesome disease in many crops, by means of greenhouse and laboratory evaluations for many years. Among a large number of chemicals tested, the derivatives having isoxazole ring showed considerable activity on controlling this disease. The general purpose of this study was to search for the most effective soil-fungicide among these 3hydroxyisoxazole derivatives.

\section{Materials and Methods}

(1) Effects of 3-hydroxyisoxazole derivatives on cucumber seedling diseases.- Effects of 3-hydroxyisoxazole derivatives substituted at 4 and/or 5-position of isoxazole ring on cucumber Fusarium wilt (Fusarium oxysporum Schlecht. f. cucumerinum Owen) and cucumber seedling damping-off (Corticium rolfsii (Sacc.) Curzi, Pythim aphanidermatum (Edson) Fitzpatrick) were studied.

Tests were conducted in a greenhouse with seedlings of cucumber (Cucumis sativus L. var. Sagamihanpaku). The inoculum, Fusarium oxysporum Schlecht. f. cucumerinum Owen, Corticium rolfsii (Sacc.) Curzi, or Pythium aphanidermatum (Edson) Fitzpatrick, was cultured on autoclaved oat grains for 2 weeks at $26 \mathrm{C}$, and was blended with sandy-loam soil collected from a paddy field ( $\mathrm{pH}$ : $4.4 / 50 \%$, CEC : $4.8 \mathrm{me} / 100 \mathrm{~g}$, total carbon : $0.3 \%$, sand : $77.1 \%$, silt : $16.0 \%$, clay: $6.9 \%$ ) in the ratio of $1: 50$ (grains : soil), respectively. Each inoculated soil was filled in $30 \times 25 \times 10 \mathrm{~cm}$ wooden box, then incubated at 25-30 $\mathrm{C}$ in a greenhouse. One hundred seeds of cucumber, being germinated for 24 hours at $26 \mathrm{C}$, were planted in each of test plots. Test chemicals formulated as $10 \%$ wettable powder were mixed with inoculated soil just before sowing, or drenched on the soil at the rate of 3 liters per sq. meter just after sowing. The growth of the seedlings and the number of infested seedlings were examined 2 weeks after the chemical treatment.

(2) Antimicrobial activities on potato-sucrose-agar (PSA) medium and in soil.- Antimicrobial activities of test compounds were examined by agar dilution method and by soil-drenching method.

Each of test compounds dissolved in dimethylformamide was diluted by sterilized water at 10 times to the desired concentration, and mixed with culture medium. The concentration of dimethylformamide in the medium was found to have no effect on the growth of organisms. C. rolfsii, $F$. oxysporum f. lycopersici, $P$. debaryanum and $R$. solani were subcultured on PSA medium for 7 days at $26 \mathrm{C}$ before use. Ten milliliters of PSA medium containing a compound at a desired concentration was poured into each Petri-dish $(9 \mathrm{~cm} \mathrm{I}$. D). After cooling, a $5 \mathrm{~mm}$ disc of agar with mycelial growth of test fungus (taken from the periphery of 7 days culture colony) was placed on the center of the solidified medium, and incubated for 7 days at $26 \mathrm{C}$. The diameter of mycelial colony was measured. The percent growth index was calculated by dividing the colony diameter of treated by that of untreated.

To determine the inhibitory effects of the compounds on the mycelial growth of C. rolfsii in soil, Tanashi soil (volcanic ash soil, $\mathrm{pH}: 6.0 / 50 \%, \mathrm{CEC}: 27.0 \mathrm{me} / 100 \mathrm{~g}$, total carbon : $4.9 \%$, sand: $60.5 \%$, silt : $30.2 \%$, clay : $9.3 \%$ ) was used. Forty grams of the soil was placed at the bottom of tall glass dish (diameter: $9 \mathrm{~cm}$, height: $6 \mathrm{~cm}$ ) and then made its surface flat. Mycelial mats of liquid culture of $C$. rolfsii were kept on cotton discs ( $4 \mathrm{~cm}$ square) placed on the soil surface, and then covered with another 100 grams of the soil. The soil surface was thoroughly drenched by $20 \mathrm{ml}$ of aqueous solution of each test compound. These were incubated for 3 days at $30 \mathrm{C}$ after chemical treatment, and the mycelial growth in each test plot from inoculum over soil surface was recorded. 
(3) Efficacy of 3-hydroxy-5-methylisoxazole (hymexazol) in the greenhouse-- The controlling effect of hymexazol on Fusarium wilt of tomato seedlings (Lycopersicon esculentum Mill var. Shinfukuju) was evaluated in a greenhouse. F. oxysporum f. lycopersici was cultured on autoclaved grains at 26 $\mathrm{C}$ for 2 weeks. Thirty grams of the infested grain was well blended with the soil sandy-loam in each test plot. The test plot was consisted of a $40 \times 60 \mathrm{~cm}$ wooden bed, in duplicate. Chemicals were applied with a watering pot at the rate of 3 liters per sq. meter once (June 24: just before transplanting, or July 3: after rooting) or twice (June 24 and July 3). In each of test plots, 20 plants grown for 2 week at $25 \mathrm{C}$ were transplanted one hour after the first chemical treatment. During this experiment the temperature was maintained at 25-30 C. The growth of the seedlings and the number of infected seedlings were examined on July 9 and July 16.

To evaluate the controlling effect on rice seedling damping-off in nursery, the sandy-loam soil was inoculated with $F$. solani, which had been isolated from diseased rice plants and cultured on autoclaved oat grains at $28 \mathrm{C}$ for 2 weeks. Four hundred rice seeds (Oryza sativa L. var. Kinmaze) were seeded in each of test plots on Dec. 15. Each of test plots was consisted of $30 \times 20 \mathrm{~cm}$, in duplicate. Chemicals were applied at the rate of 3 liters per sq. meter just after seeding. These seed-beds were remained at $32 \mathrm{C}$ for 24 hours and then at $25 \mathrm{C}$ for 20 days. Test results were examined 24 days after the ehemical treatment.

Table 1. Effects of 3-hydroxyisoxazole derivatives on soil borne plant diseases (greenhouse)

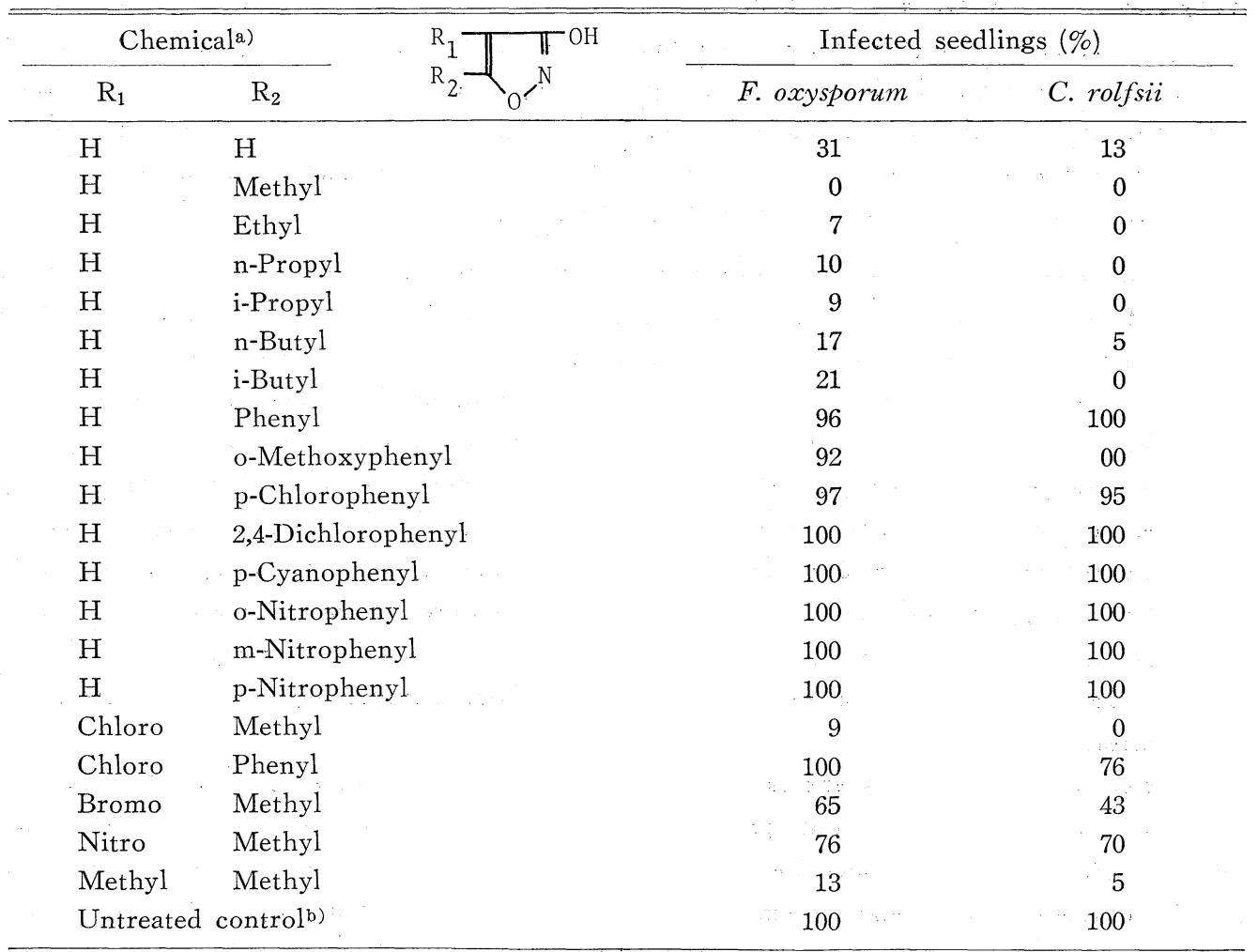

a) $10 \%$ wettable powders of test chemicals were mixed with inoculated soil at the rate of $400 \mathrm{mg}$ per $1 \mathrm{~kg}$ of the soil.

b) Inoculated with pathogen, but not treated with chemical. Data are averages of 2 replicates. 
(4) Phytotoxicity.- Phytotoxicity of chemicals in each test plot was represented by the following degree of growth inhibition.

$$
\begin{array}{cl}
+++ & \text { severe } \\
++ & \text { moderate } \\
+ & \text { slight } \\
- & \text { non-phytotoxic }
\end{array}
$$

(5) Chemicals.- 3-Hydroxyisoxazole derivatives tested in this investigation are listed in Table 1.

Benomyl [Methyl 1-(butylcarbamoyl)-2-benzimidazole-carbamate 50\% wettable powder] and Shimilton (Ethyl phenethynyl mercury $\mathrm{Hg}-2 \%$ emulsifible concentrate) were used as reference chemicals in the greenhouse evaluation.

\section{Results and Discussion}

Effects of 3-hydroxyisoxazole derivatives on cucumber seedling diseases.- As shown in Table 1 and Table 2, 3-hydroxy-5-methylisoxazole (hymexazol) was most effective against soil-borne diseases tested.: Derivatives having alkyl groups in the 5-position of the isoxazole ring were more effective than those having aryl groups substituted or not substituted. These derivatives were not severely phytotoxic to cucumber seedlings at the concentrations tested except 3-hydroxyisoxazole. The effectiveness decreased in the following order; methyl $>$ ethyl $>$ propyl $>$ butyl $>$ hydrogen. When a methyl group was substituted in the 5-position of isoxazole-ring, replacement of hydrogen at 4-position by nitro or methyl group or by chlorine or bromine atom reduced effectiveness against soil-

\begin{tabular}{|c|c|c|c|c|c|c|}
\hline \multicolumn{2}{|c|}{ Chemical } & \multirow{2}{*}{$\begin{array}{c}\text { Conc } \\
(\mu \mathrm{g} / \mathrm{ml})\end{array}$} & \multirow{2}{*}{$\begin{array}{c}\text { Phytoto- } \\
\text { xicity }\end{array}$} & \multicolumn{3}{|c|}{ Infected seedlings $(\%)$} \\
\hline $\mathrm{R}_{1}$ & $\mathrm{R}_{2}$ & & & $\begin{array}{l}\text { F. oxy- } \\
\text { sporum }\end{array}$ & C. rolfsii & $\begin{array}{c}P \text { apha- } \\
\text { nidermatum }\end{array}$ \\
\hline $\mathrm{H}$ & $\mathrm{H}$ & $\begin{array}{r}1000 \\
300 \\
100\end{array}$ & $\begin{array}{r}+ \\
+\end{array}$ & $\begin{array}{r}23 \\
50 \\
100\end{array}$ & $\begin{array}{r}0 \\
40 \\
61\end{array}$ & $\begin{array}{r}0 \\
30 \\
98\end{array}$ \\
\hline $\mathrm{H}$ & Methyl & $\begin{array}{r}1000 \\
300 \\
100\end{array}$ & $\begin{array}{l} \pm \\
-\end{array}$ & $\begin{array}{r}0 \\
2 \\
24\end{array}$ & $\begin{array}{l}0 \\
0 \\
5\end{array}$ & $\begin{array}{l}0 \\
0 \\
8\end{array}$ \\
\hline $\mathrm{H}$ & Ethyl & $\begin{array}{r}1000 \\
300 \\
100\end{array}$ & \pm & $\begin{array}{r}2 \\
14 \\
50\end{array}$ & $\begin{array}{r}0 \\
2 \\
26\end{array}$ & $\begin{array}{r}0 \\
5 \\
26\end{array}$ \\
\hline $\mathrm{H}$ & n-Propyl & $\begin{array}{r}1000 \\
300 \\
100\end{array}$ & $\begin{array}{l} \pm \\
-\end{array}$ & $\begin{array}{r}7 \\
12 \\
64\end{array}$ & $\begin{array}{r}0 \\
6 \\
44\end{array}$ & $\begin{array}{r}0 \\
11 \\
25\end{array}$ \\
\hline $\mathrm{H}$ & Phenyl & $\begin{array}{r}1000 \\
300 \\
100\end{array}$ & $\begin{array}{l}- \\
\overline{-}\end{array}$ & $\begin{array}{r}90 \\
100 \\
100\end{array}$ & $\begin{array}{l}64 \\
97 \\
96\end{array}$ & $\begin{array}{r}95 \\
99 \\
100\end{array}$ \\
\hline Chloro & Methyl & $\begin{array}{r}1000 \\
300 \\
100\end{array}$ & $\begin{array}{l} \pm \\
-\end{array}$ & $\begin{array}{r}1 \\
5 \\
40\end{array}$ & $\begin{array}{r}0 \\
0 \\
10\end{array}$ & $\begin{array}{r}0 \\
0 \\
25\end{array}$ \\
\hline Methyl & Methyl & $\begin{array}{r}1000 \\
300 \\
100\end{array}$ & $\begin{array}{l} \pm \\
-\end{array}$ & $\begin{array}{l}25 \\
50 \\
64\end{array}$ & $\begin{array}{r}0 \\
40 \\
50\end{array}$ & $\begin{array}{r}0 \\
15 \\
40\end{array}$ \\
\hline \multicolumn{2}{|c|}{ Untreated control ${ }^{\prime} a$} & & & 100 & 98 & 100 \\
\hline
\end{tabular}
borne diseases such as Fusurium wilt and damping-off.

Table 2. Effects of 3-hydroxyisoxazole derivatives on soil borne plant disease (greenhouse)

a) Inoculated with pathogen, but not treated with chemical. Data are averages of 2 replicates. 
Antimicrobial activities on PSA medium and in soil.- As shown in Table 3, among the 3hydroxyisoxazole derivatives tested 3-hydroxy-5-phenylisoxazole was most effective on PSA medium against $R$. solani, $C$. rolfsii, $F$. oxysporum and $P$. debaryanum. When this compound was drenched to the soil, however, a clear reduction of inhibitory activity was observed as compared with that on PSA medium (Table 4). The inhibitory effects of the derivatives having alkyl groups on the

Table 3. Inhibitory effects of 3-hydroxyisoxazoles on the mycelial growth of $C$. rolfsii, $R$. solani, F. oxysporum f. lysopercici and $P$. debaryanum on PSA

\begin{tabular}{|c|c|c|c|c|c|c|c|c|c|}
\hline \multirow[b]{2}{*}{ Pathogen } & \multicolumn{2}{|c|}{ Chemical } & \multicolumn{7}{|c|}{ Growth index $\left.{ }^{a}\right)$} \\
\hline & $\mathrm{R}_{1}$ & $\mathrm{R}_{2}$ & \multicolumn{7}{|c|}{ Conc $(\mu \mathrm{g} / \mathrm{ml})$} \\
\hline \multirow[t]{5}{*}{ C. rolfsii } & $\mathrm{H}$ & $\mathrm{H}$ & 45 & 70 & 90 & 94 & 97 & 98 & 94 \\
\hline & $\mathrm{H}$ & Methyl & 19 & 53 & 70 & 77 & 86 & 100 & 96 \\
\hline & $\mathrm{H}$ & Ethyl & 0 & 0 & 40 & 72 & 83 & 88 & 91 \\
\hline & $\mathrm{H}$ & n-Propyl & 0 & 0 & 0 & 70 & 88 & 98 & 101 \\
\hline & $\mathrm{H}$ & Phenyl & 0 & 0 & 0 & 12 & 40 & 92 & 98 \\
\hline \multirow[t]{5}{*}{ R. solani } & $\mathrm{H}$ & $\mathrm{H}$ & 23 & 41 & 64 & 84 & 88 & 92 & 89 \\
\hline & $\mathrm{H}$ & Methyl & 16 & 30 & 44 & 59 & 67 & 80 & 78 \\
\hline & $\mathrm{H}$ & Ethyl & 0 & 0 & 14 & 33 & 47 & 70 & 91 \\
\hline & $\mathrm{H}$ & n-Propyl & 0 & 0 & 0 & 67 & 80 & 91 & 95 \\
\hline & $\mathrm{H}$ & Phenyl & 0 & 0 & 0 & 0 & 48 & 73 & 89 \\
\hline \multirow[t]{5}{*}{ F. oxysporum } & $\mathrm{H}$ & $\mathrm{H}$ & 82 & 85 & 95 & 94 & 92 & 92 & 92 \\
\hline & $\mathrm{H}$ & Methyl & 38 & 50 & 63 & 76 & 84 & 89 & 95 \\
\hline & $\mathrm{H}$ & Ethyl & 41 & 66 & 72 & 83 & 91 & 94 & 94 \\
\hline & $\mathrm{H}$ & n-Propyl & 37 & 68 & 94 & 110 & 115 & 120 & 94 \\
\hline & $\mathrm{H}$ & Phenyl & 0 & 0 & 22 & 56 & 78 & 85 & 96 \\
\hline \multirow[t]{5}{*}{ P. debaryanum } & $\mathrm{H}$ & $\mathrm{H}$ & + & 26 & 88 & 100 & 100 & 100 & 100 \\
\hline & $\mathrm{H}$ & Methyl & 10 & 11 & 11 & 12 & 13 & 13 & 30 \\
\hline & $\mathrm{H}$ & Ethyl & + & + & 26 & 50 & 77 & 81 & 90 \\
\hline & $\mathrm{H}$ & n-Propyl & 0 & + & 18 & 53 & 84 & 100 & 100 \\
\hline & $\mathrm{H}$ & Phenyl & 0 & 0 & 0 & 25 & 74 & 100 & 100 \\
\hline
\end{tabular}

a) Deta are averages of 3 replicates.

Table 4. Inhibitory effects of 3-hydroxyisoxazoles on the mycelial growth of C. rolfsii in soil.

\begin{tabular}{|c|c|c|c|c|c|c|}
\hline \multicolumn{2}{|c|}{ Chemical } & \multicolumn{5}{|c|}{ Inhibition Index ${ }^{a}$ ) } \\
\hline $\mathrm{R}_{1}$ & $\mathrm{R}_{2}$ & \multicolumn{4}{|c|}{ Conc $(\mu \mathrm{g} / \mathrm{g}$ soil $)$} & 0 \\
\hline $\mathrm{H}$ & $\mathrm{H}$ & - & - & - & - & - \\
\hline $\mathrm{H}$ & Methyl & ++ & $+t$ & ++ & + & \\
\hline $\mathrm{H}$ & Ethyl & $+t$ & $+t$ & + & + & \\
\hline $\mathrm{H}$ & n-Propyl & ++ & ++ & + & + & \\
\hline $\mathrm{H}$ & Phenyl & + & - & - & - & \\
\hline
\end{tabular}

a) The inhibition of mycelial growth over soil surface was expressed as follows :

- : no inhibition

+ : partial inhibition

++ : complete inhibition 
5-position on PSA medium against $R$. solani and C. rolfsii were strengthened in proportion to the increase in the number of carbon atoms of alkyl groups. $P$. debaryanum was more sensitive to these derivatives than the other three fungus species. Hymexazol inhibited the mycelial growth of $P$. debaryanum at lower concentration. 3-Hydroxyisoxazole has only a weak activity against these fungi.

In soil, however, the activities of 3-hydroxyisoxazole derivatives substituted with alkyl groups at 5-position were not proportional to the number of carbon atoms of alkyl groups, and hymexazol showed the highest activity. The mycelial growth was completely inhibited by soil-drenching with $100 \mu \mathrm{g} / \mathrm{ml}$ solution of this compound.

Efficacy of hymexazol in the greenhouse.- Because of this outstanding activity, hymexazol was tested for the control of Fusarium wilt of tomato seedlings and Fusarium damping-off of rice seedlings. The effects of hymexazol were outstanding and the results were given in Table 5 and

Table 5. Effect of hymexazol on Fusarium wilt of tomato seedlings (greenhouse)

\begin{tabular}{lccccr}
\hline \multirow{2}{*}{ Tretment } & Conc & \multicolumn{2}{c}{ Application } & \multicolumn{2}{c}{ Infected plants $(\%)$} \\
& $(\mu \mathrm{g} / \mathrm{ml})$ & June 24 & July 3 & July 9 & July 16 \\
\hline Untreated controla $)$ & - & - & - & 55.0 & 100.0 \\
Hymexazol & 1000 & Yes & Yes & 0.0 & 0.0 \\
& 500 & Yes & Yes & 0.0 & 3.5 \\
& 1000 & - & Yes & 5.0 & 52.5 \\
& 500 & - & Yes & 7.5 & 57.5 \\
& 1000 & Yes & - & 0.0 & 1.0 \\
Benomyl & 500 & Yes & - & 0.0 & 11.5 \\
& 1000 & Yes & Yes & 0.0 & 0.0 \\
& 500 & Yes & Yes & 0.0 & 4.5 \\
\hline
\end{tabular}

a) Infected with pathogen, but not treated with chemical.

Table 6. Effect of hymexazol on the control of Fusarium damping-off of rice seedling. (greenhouse)

\begin{tabular}{lcccc}
\hline \hline \multicolumn{1}{c}{ Treatment } & $\begin{array}{c}\text { Conc } \\
(\mu \mathrm{g} / \mathrm{ml})\end{array}$ & $\begin{array}{c}\text { Seeds } \\
\text { emerged } \\
(\%)\end{array}$ & $\begin{array}{c}\text { Healthy } \\
\text { seedlings } \\
(\%)\end{array}$ & $\begin{array}{c}\text { Shoot } \\
\text { growth } \\
(\%)\end{array}$ \\
\hline Untreted controla) & - & 74.2 & 54.9 & 100.0 \\
Hymexazol & 600 & 93.6 & 93.6 & 98.5 \\
& 300 & 98.0 & 98.0 & 129.7 \\
$\begin{array}{l}\text { Ethyl } \\
\text { phenethynyl- }\end{array}$ & 100 & 91.3 & 89.4 & 139.3 \\
mercury & 33 & 80.4 & 71.8 & 97.3 \\
\hline
\end{tabular}

a) Infected with pathogen, but not treated with chemical. Data are average of 2 replicates.

Table 6. The test on Fusarium wilt of tomato seedlings revealed that both hymexazol and benomyl reduced the symptom development when applied at 500 or $1000 \mu \mathrm{g} / \mathrm{ml}$ at the rate of 3 liters per sq. meter once (before transplanting) or twice (before transplanting and after rooting), whereas untreated plants were completely wilted and the xylem tissues were severely discolored. Complete disease control was noted when hymexazol or benomyl was applied at $1000 \mu \mathrm{g} / \mathrm{ml}$. But the treatment after 
rooting was not satisfactory. Notable phytotoxicity was not observed. Fusarium sp. was isolated in every xylem tissue of diseased plants, but not in its of sound plants.

The test result of hymexazol for Fusarium damping-off of rice seedlings was given in Table 6 . Hymexazol was more effective than Shimilton which had been practically used to prevent rice seedlings from damping-off. And rice seedlings in the plots treated with hymexazol grew better than Shimilton or nontreated plots. Phytotoxicity was not observed.

These experiments indicate that hymexazol is the most effective soil-fungicide among the 3hydroxyisoxazole derivatives tested. It is effective to a number of soil-borne diseases, especially to these caused by Fusarium spp, Pythium spp, Corticium sp and some isolates of Rhizoctonia solani. And it works better when used preventively, and is applicable to growing crops without phytotoxicity. The plants treated with this compound grow better, and the roots are white and thick. These facts seem to be favorable for rooting and growth after transplanting, and have good influence on harvest.

The characteristics of this compound as soil-fungicide is expected to be informed in the next reports.

\section{Acknowledgement}

The authors thank Dr. M. Ishida for assistance in proofreading the manuscript. We also wish to acknowledge the techinical assistance of Mr. K. Nakagami, Mr. Y. Kondo and Mr. K. Ota.

\section{Literature Cited}

1) Iwai, I. and Nakamura, N. (1966). Chem. Pharm. Bull. 14: 1277 1286.

2) Tomita, K., Nagano, M., Yanai, T., Oka, H., Murakami, T. and Sampei, N. (1970). Ann. Sankyo Res. Lab. 22 : 215-220.

3) Takahi, Y. and Tomita, K. (1972). Ann. Phytopath. Soc. Japan $36: 196$ (abstr).

\section{和文摘 要}

\section{3-Hydroxy Isoxazole 誘導体の土壤殺菌剂としての効果 その化学構造と活性について} 高日幸義・中西逸朗 富田和男・上村昭二

Isoxazole ring の 4 または 5 位に置換された化合物を供試して, キュウリ苗のつる割病 (F. oxysporum f. cucumerinum), 苗立枯病 (C. rolfsii, P. aphanidermatum) に対する効果, おょびシャガイモ煎汁寒天培地上, 土堙中での抗菌活性を比較検討した。

温室試験一Isoxazole ring の 5 位に alkyl 基または水素を導入した化合物は，aryl 基を導入した化合物よ り有効で, その効力順位は methyl>ethyl>propyl>butyl>hydrogen となったが，さらに 4 位に nitro 基, methyl 基, $\mathrm{Cl}, \mathrm{Br}$ などを導入すると効果が劣った。

室内試験一Isoxazole ring の 5 位に alkyl 基を導入した化合物のジャガイモ煎汁寒天培地上での R. solani, C. rolfsii, P. debaryanum に対する抗菌活性は, alkyl 基の炭素数に比例して活性が高くなる傾向にあったが， F. oxysporum に対してはそのような傾向は認められなかった。一方, 土壌中でのC. rolfsii に対する抗菌活性 は alkyl 基の炭素数に比例せず,ハイメキサゾール (3-hydroxy-5-methylisoxazole) がもっとも有効であった。 
これに対して, isoxazole ring の 5 位を phenyl 基で置換した場合はジャガイモ煎汁寒天培地上での抗菌活性は 非常に高いが，それを土壤に施用するととの抗菌活性が著しく低下する。

このようにして, ハイメキキサン゙ールを供試化合物中でもっとも有効な化合物として選び出し, 温室内で実用 効果を検討した。 